\title{
Heroines in Belgium and Serbia
}

\section{Introduction: plucky nurses}

At the outbreak of the First World War British women volunteered for war service in such numbers that organisations such as the Red Cross and the Order of St John of Jerusalem found themselves, initially, overwhelmed. Many of those who offered to nurse the wounded held no nursing qualifications of any kind, and had to wait until they had passed VAD examinations, or acquired full nurse-training in recognised training hospitals, before they could gain acceptance for military service. American women, too, were eager for participation in war - even though their country was to remain neutral until 1917. American writer Margaret Deland observed that 'of all the amazing things that have come bubbling and seething to the surface of life during these last three and a half years, there has been nothing more amazing to me than this exodus of American girls', adding that she believed that such things could only have happened in the USA, 'where fathers and mothers have so very little to say as to the behavior of their daughters.' ${ }^{1}$ But British women, too, anxious to prove their 'pluck' and worth, offered themselves for military nursing service in their tens of thousands. Some were so wealthy and powerful that, far from finding themselves barred by parental - or any other - authority, they were able, in the early months of war, to take entire hospital units overseas to France and Belgium. It was only in early 1915, after the official military medical and nursing services had established a structured network of hospitals and transport services on the Western 
Front, that such volunteer units began to come under more formal military control.

In the summer of 1914, the sympathies of the British people were as much with Serbia as with Belgium. ${ }^{2}$ Many of the volunteer units that had travelled to Belgium during the earliest months of the war, only to be forced out again by the advancing German army, transferred their services to Serbia in 1915. Both nations had a significant hold upon the popular imagination. Whilst Belgium was the victim - the country from which refugees poured in their thousands - Serbia was seen as the small and defenceless, but noble and patriotic, nation that had defied tyranny. The plight of the Serbian people moved several women's volunteer groups to offer their services. The prospect of travelling thousands of miles from home to support a people who were seen as fierce defenders of a noble cause seemed to some a romantic adventure. Yet, the leaders of such expeditions - women such as Elsie Inglis, and Leila, Lady Paget - were very serious in their approaches to what they saw as, at heart, a patriotic endeavour. ${ }^{3}$ Their efforts, unsurprisingly, ended in disaster. Some were imprisoned by their German and Bulgarian adversaries; others found themselves on a desperate and life-threatening trek across the Albanian Alps.

\section{The duchess-directrice: Millicent Sutherland and her ambulance}

Some wealthy and aristocratic women found that war nursing could be a welcome dramatic episode in an otherwise safe and privileged life. For Millicent, Duchess of Sutherland, war-torn Belgium and northern France were so far removed from anything she had previously known that her involvement seemed a great adventure - an epic journey through an unknown terrain. It is not clear whether her book Six Weeks at the War was written with deliberately propagandist intent. ${ }^{4}$ It may be that her account unreflectively reproduces the perceptions of her own class. If so, it illustrates how submerged those perceptions were in nationalism. Her beliefs in the right of the British cause and the brutality of the German nation run through her short account of the time she spent in Belgium in the first weeks of war. She bemoans the power that is wielded by 'Prussia's rulers' over the German people. ${ }^{5}$ 
It is not the millions of soldiers who should be blamed for the catastrophe of war: they are under the control of their military masters. Yet, British men and women drawn into the same war remain pure and this is particularly true of the nurses she has enlisted into her ambulance, whose courage and selflessness are a recurring theme of her narrative. For her, only the annihilation of the German army can bring the war to an end, and that goal is a just one. ${ }^{6}$

Lady Millicent St Clair-Erskine was born in 1867, and married into the British aristocracy, to become Duchess of Sutherland, in 1884. Although she began her wartime nursing service by enrolling with the French Red Cross in Paris on 9 August 1914, she soon decided that she could best serve the allied war effort by forming her own hospital unit.' The 'Millicent Sutherland Ambulance' was established under the auspices of the Belgian 'Service de Santé des Armées' and was formed with the support of the Belgian Red Cross. Dr Antoine Depage, an influential Brussels surgeon, who at that time was working closely with Edith Cavell, gave strong support to the initiative, and was declared by Millicent to be 'a man to brush away all red tape and ineptitude. ${ }^{8}$ Millicent sent to Britain for Guy's Hospital surgeon Oswald Morgan, eight nurses, and a stretcher-bearer.

Memoirist Elsie Knocker (Baroness T'Serclaes) was to comment years later that many of the First World War's earliest field hospitals were 'splendidly freelance' in a way that would never again be possible. ${ }^{9}$ The British class system was, in Paul Fussell's words, 'intact and purring smoothly, ${ }^{10}$ and significant numbers of upper-class British women appear to have taken it for granted that they should be at the heart of the war effort, whether they possessed the required skills or not. In this sense, they were mirroring the behaviours of their French counterparts, many of whom entered hospitals to work as 'lady-nurses' with no qualifications of any kind. ${ }^{11}$ The wealth, social influence, and confidence of even the most aristocratic volunteers were not sufficient to persuade their own compatriots in the British Royal Army Medical Corps to incorporate them into its ranks at the outbreak of war (except as VADs). But a severe shortage of fully trained nurses on the European Continent meant that the beleaguered Belgian and French Services de Santé were only too anxious to accept offers, which ranged from individual service in existing military hospitals to the establishment of whole field hospitals and 
ambulance units. The impression is given by some accounts that, in the early weeks of the war, Belgium was teeming with groups of wealthy eccentrics, working as hospital directors, nurses, doctors, and ambulance drivers. ${ }^{12}$ Amongst the most colourful were the First Aid Nursing Yeomanry, a unit of wealthy, upper-middle-class and aristocratic female ambulance drivers who were said to have arrived on the Continent wearing fur coats. ${ }^{13}$

The first Millicent Sutherland Ambulance was established in a convent in Namur, owned by the Soeurs de Notre Dame. Soon after the unit's arrival, the Germans began to shell the town. ${ }^{14}$ Millicent quoted an excerpt from her original diary to describe the events of late August:

Never shall I forget the afternoon of August 22 ... Six motor-cars and as many wagons were at the door, and they were carrying in those unhappy fellows. Some were on stretchers, others were supported by willing Red Cross men. One or two of the stragglers fell up the steps from fatigue and lay there. Many of these men had been for three days without food or sleep in the trenches ... So many of the men were in a state of prostration bordering almost on dementia, that I seemed instantly enveloped in the blight of war. I felt stunned - as if I were passing through an endless nightmare. ${ }^{15}$

The bombardment continued, and walking patients took shelter in the cellars of the convent. Millicent's eight nurses, however, were 'most courageous', remaining above ground with those who were helpless and bedfast. Millicent commented that 'no one, until these awful things happen, can conceive the untold value of fully-trained and disciplined British nurses.' ${ }^{16}$

Eventually the Germans entered Namur. A fire - believed to have been started deliberately - spread quickly to engulf a large part of the town. Millicent and her nurses again remained at their posts and reassured their patients. As she describes these events, Millicent recounts how she 'felt as if I were actually living some book of adventure, such as I had read in my youth. ${ }^{17}$ Her tendency to recount the whole episode as if it were part of an adventure story is striking, and is typical of this genre of war writing. ${ }^{18}$ Following the German occupation, Millicent and her party were escorted on foot to Brussels - a long and difficult journey; but Millicent claims to have shrugged it off as no further than she might walk in a day's golfing. From Brussels they returned home by car and boat via Rotterdam. ${ }^{19}$ 
By 23 October, Millicent was back on the Continent. The 'Millicent Sutherland Ambulance Car Convoy' landed in Dunkirk and established a 100-bed hospital for Belgian and French soldiers at the Hotel Belle Vue in Malo-les-Bains near Dunkirk. ${ }^{20}$ In the summer of 1915, the hospital was transferred to Bourbourg, twelve miles from Dunkirk and outside the range of the enemy's guns. Here, it was famously known as 'the camp in the oat field', and was the subject of a series of paintings by Victor Tardieu. ${ }^{21} \mathrm{On}$ 15 October that year, the hospital was taken over by the British Red Cross, attached to No. 35 General Hospital near Calais, and began to take in British wounded. Following subsequent moves to Longuenesse, Hazebrouck, and Roublaix, the hospital was finally demobilised on 20 November 1918.22

The 'Millicent Sutherland Ambulance' experienced numerous changes of identity, as well as several geographical moves bringing it alternately closer to and further from the front lines. It is Millicent's first 'six weeks at the war', however, that are best known to a modern readership. The pages she wrote so hastily following her return from Belgium in October 1914, incorporating large amounts of text from her personal diary, offer an immediate and, at times, compelling account of the fate of volunteer field hospitals during the earliest weeks of the war.

\section{Escaping the German advance: a war nurse's diary}

The establishment of large numbers of ad hoc medical units and temporary field hospitals gave British nurses unexpected opportunities to serve close to the front lines. One nurse, whose anonymous account of her adventures in Belgium was published as A War Nurse's Diary: Sketches from a Belgian Field Hospital, describes feelings, at the outset of war, that were typical of a population gripped by 'war fever': 'the great upheaval sent its waves of excitement beating against every shore till it touched the whole world'. The writer was working in a hospital in England. She had joined neither the Reserve of the QAIMNS nor the Territorial Force Nursing Service, and so was forced to watch with 'an almost bitter envy' as many of her colleagues were called away for military service. ${ }^{23}$ Enquiries and offers of service to both voluntary and official services yielded only refusals. It was 
reported that about 30,000 nurses were available, which, at that time, was believed to be 'about one nurse to each soldier' - clearly an estimate that was both inaccurate and inadequate. ${ }^{24}$

Eventually, this nurse author's efforts were rewarded and she was taken on by a volunteer unit bound for Antwerp. Her sense of excitement and adventure, along with her recognition that she was joining an unofficial - and perhaps quite disorganised - expedition are illustrated by her comment on the preparations she and her colleagues made: 'The lady who was the organizer of our hospital had not, I should judge, any previous experience of hospitals or their management. We all felt this, and therefore were quite prepared at an early date to fall into the hands of the Germans, so, as a precaution, we nurses each provided ourselves with a tube of morphia tablets to take in any emergency.25 In Antwerp, the nurses established their hospital in a grammar school (formerly a duke's palace) on the Boulevard Leopold. The author offers vivid descriptions of her patients' wounds, commenting that the antiseptic treatment of wounds in a British civilian hospital was very different from 'dealing with mangled and shattered flesh where the wounds are filled with mud, torn clothing and shrapnel. ${ }^{26}$ The bombardment of Antwerp brought with it large numbers of burn victims, some with such severe facial injuries that nurses had to 'force' openings through which to insert tubes to feed their patients. ${ }^{27}$

Like Millicent, the author of A War Nurse's Diary was keen to emphasise the courage of nurses under German bombardment. Her situation in Antwerp placed her in a field of great danger, and her description of her experience of shell-fire is particularly vivid:

a boom far away, immediately followed by a new whistling scream increasing in volume and intensity till it became the roar of a train in a tunnel. It skimmed over our heads, literally raising our hair in its passage. This ended in a large, full explosion. Then all was silence for a breathless second, when the terrified roar of a wounded animal rent the air, like that of a great bull bellowing. A pistol shot followed, and silence ensued again. I was seized with an uncontrollable ague, whilst my friend reached out her hand and said, 'Remember we are British women, not emotional continentals. We've got to keep our heads.' ${ }^{28}$

This writer chooses to reveal the 'qualities' of British women again when describing the volunteer hospital's departure from Antwerp as 
part of a mass-evacuation of Belgium. The staff managed to commandeer five of the London buses that had provided transport for British marines in Belgium. Filling these with patients, they joined a stream of refugees heading for Ostend. Their fourteen-and-a-half-hour journey was both gruelling and hazardous, with nurses taking turns to sit inside the vehicle with the seriously wounded, and outside on the top deck with less dangerously ill cases:

Just before we started a tall Marine in a navy jersey and sailor's cap was helped in. He sat in the corner next to me. All his ribs were broken down one side, and he had no plaster or support. Opposite me were two Tommies with compound fractures of the leg. I placed both legs on my knees to lessen the jolting. The Marine suffered in silent agony, his lips pressed tightly together, and his white face set. I looked at him helplessly, and he said 'Never mind me, Sister; if I swear don't take any notice.' Fortunately, they had pushed in two bottles of whiskey and some soda-syphons; I just dosed them all around until it was finished. Placing the Marine's arm around my shoulders, I used my right arm as a splint to support his ribs, and so we sat for seven and a half hours without moving. ${ }^{29}$

Following her escape from the German advance, this nurse spent only a few weeks in Britain before returning to the front lines. She travelled with the Duchess of Sutherland Ambulance, but was then placed in a field hospital in Furnes. Attached to her hospital was 'a most interesting body of people': the 'Hector Munro Flying Ambulance Corps. ${ }^{30}$ The eccentric Dr Munro, along with a group of philanthropic British volunteers, had set up a British unit which provided a fleet of ambulances to ferry the wounded directly from the battlefield to a field hospital behind the lines. The ambulance had, only after some persuasion, been recognised and supported by both the Belgian and the British Committees of the Red Cross. ${ }^{31}$ Munro, 'the essence of the absent-minded professor, ${ }^{32}$ was, in some ways, more forward-thinking than his appearance and manner suggested. He was keen to promote women's rights, and in addition to hiring several female trained nurses, he invited a number of women to work in his ambulance as volunteer nurses or drivers. Among these were Helen Gleason, the American wife of a war correspondent; the aristocratic Lady Dorothie Fielding; and novelists Sarah Macnaughtan and May Sinclair. ${ }^{33}$ The unit's first ambulance had been established in the first weeks of war at the Flandria Palace Hotel in Ghent, ${ }^{34}$ but 
had been forced, like so many other British units, to escape ahead of the rapid German advance and relocate in a more permanent base in Furnes, well behind the front-line trenches. From here, its drivers went out on nightly missions to rescue the wounded from the Battle of the Yser and the First Battle of Ypres. ${ }^{35}$

The author of A War Nurse's Diary offers deliberately graphic descriptions of the war wounds she encountered while working with severely damaged patients in forward field dressing stations. She describes standing by 'grievously stricken men it is impossible to help, to see the death-sweat gathering on young faces, to have no means of easing their last moments', adding: 'this is the nearest to Hell I have yet been. ${ }^{36}$ Munro's unit was broken up in November 1915, when six of its ambulances were placed under the control of the French Service de Santé. ${ }^{37}$

\section{Nurse fighters on the Serbian Front}

Among the most unusual accounts produced by volunteer nurses is that of Flora Sandes, who began her wartime career as a volunteer with a British hospital unit and ended it as a fighter with the Serbian army. Angela Smith has suggested that, by actually fighting on the field of battle, Sandes, 'inadvertently, struck a blow for the feminist cause. ${ }^{38}$ After travelling to Salonika, and then into Serbia, Sandes remained behind when other British medical personnel left the country ahead of the Bulgarian advance. Her published diary is a chronicle of her wartime 'adventures'. One episode describes how she is sitting in bed in a small hotel in Prilip, listening to someone attempting to force an entry into her room, and watching, from the window, 'the most villainous-looking Turks squatting about at their supper. These, I tell myself, are the ones who will come in and cut my throat if Prilip is taken to-night, as I don't think any responsible person in the town knows I am here. However, if I live through the night things will probably look more cheery in the morning. ${ }^{39}$ The deliberately casual tone of Sandes's writing is probably intended to convey a sense of her coolness and courage.

Sandes obtained a posting at a mobile field ambulance serving the Second Regiment of the Serbian Army. Her description of her arrival at the ambulance is full of a sense of adventure, and could have 
come straight from the pages of a Bessie Marchant novel. ${ }^{40}$ She - the well-bred Englishwoman - 'roughs it' with the Serbian army:

It seemed a bit of a problem where I was to sleep, but eventually some of the soldiers turned out of one of their small bivouac tents. These tents are only a sort of little lean-to's [sic], which you crawl into, just the height of a rifle, two of which can be used instead of poles. You seem a bit cramped at first, but after I had lived in one for a couple of months I did not notice it. ${ }^{41}$

The tone of this passage is typical of that of the book as a whole. Even when its heroine is wounded, her account never evokes any real sense of fear. The Serbian soldiers are portrayed as a set of amiable roughnecks, and Sandes's writing sanitises the realities of war. Eventually, Sandes enlisted as a soldier in the Serbian army and rose to the rank of sergeant. Upon returning home to England, she found it almost impossible to tolerate wearing women's clothes and assimilated only with difficulty back into civilian life. ${ }^{42}$ And yet an unconscious - and entirely instinctive - sense of herself as a woman who ought to be protected comes through in her writing.

Another woman who projected a heroic, masculinised image of herself while clearly retaining a deep-rooted sense of her own femininity was Mabel St Clair Stobart, whose writings were based on her extensive experience of wartime hospital management in both the Balkan War of 1912 and the First World War. Her hard-hitting memoir, The Flaming Sword in Serbia and Elsewhere, offers vivid descriptions of the horrors of war. ${ }^{43}$ Stobart's deliberate reference to the biblical sword that debarred mankind from the Garden of Eden expressed her sense that warfare was a fall from grace. Her message was clearly stated: human society - controlled by men - had become militaristic and, therefore, dangerously destructive. If women had political influence war might be averted. And yet, society's rationale for debarring women from the exercise of political authority was predicated on the supposed military weakness of the female - the inability of women to endure the hardships of war. Stobart's avowed mission was to overturn society's delusions. ${ }^{44}$ She aimed to show, both by example and through her writing, that women were just as capable as men of taking on leadership roles in wartime, and yet that they were also naturally opposed to warfare because of their nurturing and humanitarian qualities. ${ }^{45}$ To prove her points, Stobart depicted women participating in the humanitarian efforts of the 


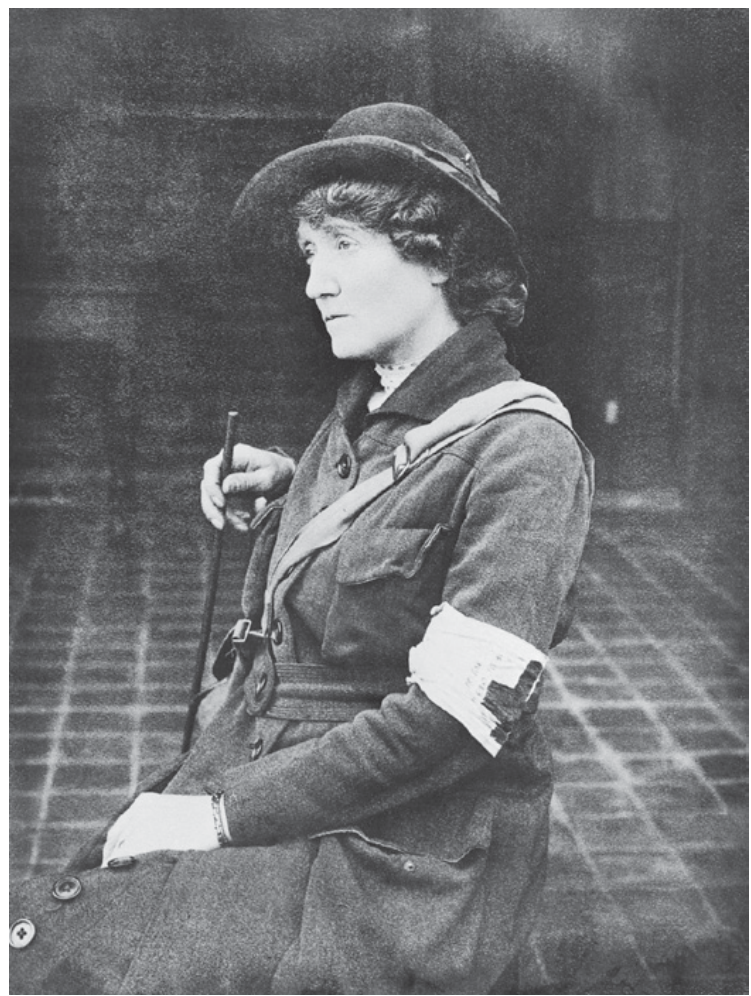

Figure 1 Portrait of Mabel St Clair Stobart

military medical services, and taking on (particularly in her own case) challenging leadership roles.

Mabel St Clair Stobart established her Women's Sick and Wounded Convoy Corps (WSWCC) in 1909, the year in which the VADs were formed. ${ }^{46}$ Her purpose was to create an entirely female corps that would be capable of performing humanitarian service, without significant male support, in time of war. The work was deliberately experimental - its purpose to demonstrate that women could exhibit the same level of strategic prowess, courage, and toughness as men. To this end, Stobart's group prepared for a future war by training vigorously on the cliffs above her home at Studland in Dorset. During the Balkan War, in 1912, they spent seven weeks in Serbia offering aid to 
the sick and wounded, and because of this prior experience, Stobart considered the WSWCC to be ready for action when the First World War began in 1914. She took a group of nurses, doctors, and volunteers to Belgium in August. ${ }^{47}$ Their work was short-lived; their unit was overtaken by the rapid German advance and they were forced to return to Britain.

Stobart next decided to take her unit to Serbia, a region with which she was already familiar. The WSWCC undertook humanitarian work among both military and civilian populations until, once again, they were forced to retreat - this time ahead of a joint German and Bulgar advance. But flight itself was an opportunity for publicity, and Stobart's leadership of her unit as it crossed the Albanian Alps in the winter of 1915 became the stuff of legend, as she - 'The Lady of the Black Horse' - forged a path across some of the most rugged and dangerous mountains of Eastern Europe. ${ }^{48}$ An image of her on horseback appeared in several daily newspapers, and was (in terms of its power and reach) reminiscent of a much earlier hugely influential image of Florence Nightingale in The Times as 'The Lady with the Lamp' ${ }^{49}$ Here, however, the similarities end: Nightingale's image was that of a vulnerable woman in a stark, military environment; Stobart's featured a woman in martial attire seated astride a black horse in a mountain ravine - she was 'A Lady who was made a Major. ${ }^{50}$

Stobart's writing is at its least convincing when it adopts a didactic, polemical style. It is her story itself that demands attention. Without indulging in any too-obvious self-promotion, she comes across to the reader as a courageous, self-possessed, and commanding personality. Her accounts of the setting-up of her field hospital in Kragujevatz, and of the expansion of her humanitarian work among the Serbian people through a network of dispensaries, impress with evidence of their detailed planning and obvious effectiveness. It is, however, her epic saga of her journey through the Albanian Alps as part of the massive exodus of fleeing refugees that really commands attention. We read of how she insisted upon leading her convoy on horseback; and of how she worked with great patience and determination to keep her unit together, on track, and supplied, during its gruelling trek over the mountains to safety. ${ }^{51}$ 
Mabel St Clair Stobart's intent was both feminist and pacifist. She insisted that there was an essential correspondence between the two. Towards the end of her account, she adopts a reflective tone:

This thought came to me vividly one summer night in Serbia. It was during the typhus epidemic, and I stumbled unawares upon an open grave. It was three-quarters full of naked corpses. They were typhus victims. They had been prisoners of war, and the grave would not be closed until there were enough dead to fill it. Heavy rain had fallen, and the bodies were half-submerged in water; but I saw one man above the others. His body, long and strong-limbed, was all uncovered, but his face, fine featured, proudly ignorant of the ignominy, his face was covered with - flies; filthy, bloodsucking flies ... The glamour, the adventure, the chivalry, which of old gilded the horrors of war, have vanished. War is now a bloody business; a business for butchers, not for high-souled gentlemen. Modern militarism involves tortures and extermination, not only of the fighting, but of the non-fighting portion of the population, in a manner which would have shocked even the heroes of the Old Testament. ${ }^{52}$

Stobart, perhaps unwittingly, draws a distinction between modern militarism with its 'tortures and exterminations' and the chivalrous warfare of earlier times. This perhaps undermines her argument that warfare - always a masculine pursuit - has always been a brutal and entirely unnecessary business. Stobart's writings stand alongside those of other female commentators on the war - women such as Catherine Marshall, who argued that the female perspective differed from that of men, because women's natural role in life was to create, rather than to destroy, life, ${ }^{53}$ or Sylvia Pankhurst, whose pacifism stemmed from her observations of the impact of war on the most vulnerable members of society: the impoverished women and children of London's East End. ${ }^{54}$

Travelling with Stobart was Olive Aldridge, who described her experiences in Serbia, working at one of the village dispensaries established by the WSWCC. She joined, in November, the retreat through Montenegro and Albania. Like Stobart herself, Aldridge produced an account that focused on the endurance and fortitude of the British women who supported the Serbian campaign. ${ }^{55}$ Alongside her account stands that of Ellen Chivers Davies, who commented on the dedication of the British nurses in Serbia during the typhus epidemics of 1915 , when 'the Sisters worked as if driven by a fury of pity which 
could only find expression in work. ${ }^{56}$ In January 1916, the British Journal of Nursing produced a column praising the 'British grit' of those nurses who had joined the retreat from Serbia, choosing to present it in rousing propagandist terms as 'the quality that is going to win the War. ${ }^{57}$

\section{A quest too far: the death of Sarah Macnaughtan}

Some nurse volunteers travelled well beyond Serbia in their determination to serve the war effort. Sarah Macnaughtan's book $A$ Woman's Diary of the War reads as an epic travel saga. Macnaughtan appears to have been driven, not only by the wish to help her fellow countrymen, but also by a quest for adventure and a need to prove herself. In this sense, her motivation - and her fate - can be seen as similar to those of many of the combatants she nursed. Macnaughtan, although not a trained nurse, had considerable wartime nursing experience. She was in Antwerp with Mabel St Clair Stobart's unit during the first weeks of the war, and she provides one of the most vivid extant descriptions of the German bombardment of that city. Demonstrating a determined 'stiff upper lip', she refers to the German shelling as 'a little startling' with its 'curious sound of rending, increasing in violence as the missile comes towards one, and giving one plenty of time to wonder, if one feels so disposed, whether it intends to hit one or not. ${ }^{58}$ This deliberate and studied nonchalance belies the intensity of Macnaughtan's feelings, which are revealed in a personal diary, collated after her death by her niece, Betty Salmon, and published as My War Experiences in Two Continents. ${ }^{59}$

Macnaughtan appears to have admired what she saw as the peculiarly British qualities of courage and stoicism, and worked hard to display such qualities herself - and to project them in her writing. She comments on how 'The Britisher was born cheery. Even when they were "gassed" they called out, "All right, Allemands, put another penny in the meter!"' ${ }^{60}$ It was probably the desire to imitate such extraordinary and openly eccentric courage that led Macnaughtan to take risks that led to her eventual death from infectious disease following an abortive expedition to the East. 
Following the retreat and capture of Mabel St Clair Stobart's unit in Belgium, Macnaughtan served for several months with Hector Munro's Flying Ambulance Corps in Furnes, and it was during this time that she wrote A Woman's Diary of the War. The book reads as a treatise on British courage and endurance. Not only does it dwell upon the 'unfailing pluck' of the stalwart British nurse, it also philosophises upon how combatants viewed death:

And the reality lies also in the extraordinary sense of freedom which war brings ... Soldiers know this, although they can never explain it. They have been terrified. They have been more terrified than their own mothers will ever know, and their very spines have melted under the shrieking sounds of shells. And then comes the day when they 'don't mind'. Death stalks just as near as ever, but his face, quite suddenly, has a friendly air. ${ }^{61}$

These words hold a tragic irony for the reader who views them alongside Macnaughtan's later diary entries. After serving for several months with the Hector Munro Flying Ambulance Corps and then running a soup kitchen at Furnes station, Macnaughtan travelled to Russia in October 1915. Deciding that her services could be most effective on the 'Persian Front', she travelled deep into Armenia, where she contracted a serious infectious disease. Helpless, without support, and unable to travel home, she wrote in her diary of how she had 'lost count of time' - how she was just waiting, 'hoping someone will come and take me away, though I am now getting so weak I don't suppose I can travel.'. ${ }^{62}$ The 'friendly air' of death was no longer near when Macnaughtan wrote sadly: 'One wonders whether there can be a Providence in all this disappointment. I think not. I just made a great mistake coming out here, and I have suffered for it. Ye gods, what a winter it has been - disillusioning, dull, hideously and achingly disappointing!' On a separate page, which she headed 'Memories of Home', she wrote:

It is too odd to think that until the war came I was the happiest woman in the world ... I can hardly believe now in my crowds of friends, my devoted servants, my pleasant walk, the daily budget of letters and invitations, and the press notices in their pink slips ... The joy, almost the intoxication of life that has been mine. Of course, I ought to have turned back at Petrograd! But I thought all my work was before me ... And now I have reached the end Persia! And there is no earthly use for us, and there are no roads. ${ }^{63}$ 
Macnaughtan did eventually obtain help, and reached home in the early summer of 1916. A few weeks before her death, she accepted the award of 'Lady Grace of the Order of St John of Jerusalem'. On her gravestone at Chart Sutton are carved the words:

In the Great War, by Word and Deed, at Home and Abroad.

She served her Country even unto Death. ${ }^{64}$

\section{Conclusion: heroines on Western and Eastern Fronts}

Some of the earliest published accounts of wartime hospital work were written by wealthy women belonging to Britain's social elite. Very few were trained nurses, but all were fascinated by what they saw as the power of nursing to act as a vehicle through which women might make important contributions to the allied war effort. For some writers, such contributions made an important political point: they demonstrated that women, as well as men, were capable of being actors on a world stage and, therefore, had the right to participate in political decision-making. For women such as Mabel St Clair Stobart, wartime hospital service would win women the right to vote. For a few - and for Stobart in particular their motivations went beyond merely proving that women could take on significant wartime roles. Offering humanitarian service actually demonstrated their commitment to peace. Yet few were as determinedly pacifist as Stobart. Indeed, some - notably Flora Sandes - seem to have been driven by a personal desire to participate in military action. Sandes clearly took pride in her service with the Serbian army. At no point in her book does she pause from her narrative to make a political point. Her 'blow' for female emancipation was, as Angela Smith asserts, an inadvertent one. ${ }^{65} \mathrm{Few}$ women wrote treatises that were so obviously political as Stobart's. Many - notably Millicent, Duchess of Sutherland - appear to have had a sense that their experiences and contributions were so extraordinary that they must set them down for others to read. Doing so was, in some ways, an act of self-promotion. It was also a means of revealing both the intensity and significance of nursing work and the strength of character of the nurse herself. 


\section{Notes}

1 Margaret Deland, Small Things (New York: D. Appleton, 1919): 57.

2 On the wartime propaganda that helped evoke and strengthen these sympathies, see Cate Haste, Keep the Home Fires Burning: Propaganda in the First World War (London: Allen Lane, 1977); Peter Buitenhuis, The Great War of Words: Literature as Propaganda, 1914-18 and After (London: B. T. Batsford, 1989 [1987]): 10-12; Trudi Tate, Modernism, History and the First World War (Manchester: Manchester University Press, 1998): 41-63; Alan Kramer, Dynamic of Destruction: Culture and Mass Killing in the First World War (Oxford: Oxford University Press, 2007).

3 Elsie Inglis, 'The Tragedy of Serbia', The Englishwoman, 30 (1916): 166; Lady Leila Paget, With Our Serbian Allies (printed for private circulation, 1916), 34602, Imperial War Museum, London; Leah Leneman, In the Service of Life: The Story of Elsie Inglis and the Scottish Women's Hospitals (Edinburgh: Mercat Press, 1994). On the work of the Scottish Women's Hospitals, see also: Jane McDermid, 'What's in a Name? The Scottish Women's Hospitals in the First World War', Minerva: Women and War, 1.1 (2007): 102-14; Costel Coroban, 'The Scottish Women's Hospitals in Romania during World War I', Valahian Journal of Historical Studies, 14 (2010): 53-68. On the fate of those units that remained in Serbia, see: Angela K. Smith, "Beacons of Britishness": British Nurses and Female Doctors as Prisoners of War', in Alison S. Fell and Christine E. Hallett (eds), First World War Nursing: New Perspectives (London: Routledge, 2013): 35-50.

4 Millicent, Duchess of Sutherland, Six Weeks at the War (London: The Times, 1914).

5 Millicent, Duchess of Sutherland, Six Weeks at the War, xiii.

6 Millicent, Duchess of Sutherland, Six Weeks at the War, xiii-xiv.

7 Denis Stuart, Dear Duchess: Millicent Duchess of Sutherland (1867-1955) (Newton Abbot: David and Charles, 1982).

8 Millicent, Duchess of Sutherland, Six Weeks at the War: 10. On Depage see also: Baroness de T'Serclaes, Flanders and Other Fields (London: George G. Harrap, 1964): 69-79.

9 T'Serclaes, Flanders and Other Fields: 36, 70. There were numerous similarly 'freelance' expeditions to France. See, for example: Dorothy Cator, In a French Military Hospital (New York: Longmans, Green, 1915). See also: Christine E. Hallett, Veiled Warriors: Allied Nurses of the First World War (Oxford: Oxford University Press, 2014): Chapter 1.

10 Paul Fussell, The Great War and Modern Memory (Oxford: Oxford University Press, 2000 [1975]): 19.

11 Margaret Darrow, 'French Volunteer Nursing and the Myth of War Experience in World War I', American Historical Review, 101.1 (1996): 80-106; Margaret Darrow, French Women and the First World War: War Stories from the Home 
Front (New York: Berg, 2000); Katrin Schultheiss, Bodies and Souls: Politics and the Professionalization of Nursing in France, 1880-1922 (Cambridge, MA: Harvard University Press, 2001).

12 See, for example: T'Serclaes, Flanders and Other Fields: 36; Anon., A War Nurse's Diary: Sketches from a Belgian Field Hospital (New York: Macmillan, 1918): 1-54; Sarah Macnaughtan, A Woman's Diary of the War (London: Thomas Nelson and Sons, 1915): passim.

13 Janet Lee, War Girls: The First Aid Nursing Yeomanry in the First World War (Manchester: Manchester University Press, 2005).

14 Millicent, Duchess of Sutherland, Six Weeks at the War: 21.

15 Millicent, Duchess of Sutherland, Six Weeks at the War: 26-8.

16 Millicent, Duchess of Sutherland, Six Weeks at the War: 27-8.

17 Millicent, Duchess of Sutherland, Six Weeks at the War: 37-8.

18 See also, for example: Violetta Thurstan, Field Hospital and Flying Column: Being the Journal of an English Nursing Sister in Belgium and Russia (London: G. P. Putnam's Sons, 1915); Anon., A War Nurse's Diary; Helen Dore Boylston, 'Sister': The War Diary of a Nurse (New York: Ives Washburn, 1927).

19 Millicent, Duchess of Sutherland, Six Weeks at the War: 78-106.

20 Laurence Binyon, For Dauntless France: An Account of Britain's Aid to the French Wounded and Victims of the War. Compiled for the British Red Cross Societies and the British Committee of the Red Cross (London: Hodder and Stoughton, 1918): 48.

21 Natasha McEnroe and Tig Thomas, The Hospital in the Oatfield (London: Florence Nightingale Museum, 2014): passim.

22 Stuart, Dear Duchess: passim.

23 Anon., A War Nurse's Diary: 3.

24 Anon., A War Nurse's Diary: 4.

25 Anon., A War Nurse's Diary: 4-5. It may be that this nurse was a part of the unit that was led by Mabel St Clair Stobart, who was to prove herself an able commander and hospital director.

26 Anon., A War Nurse's Diary: 19.

27 Anon., A War Nurse's Diary: 20.

28 Anon., A War Nurse's Diary: 21-2.

29 Anon., A War Nurse's Diary: 28-9.

30 T'Serclaes, Flanders and Other Fields; Diane Atkinson, Elsie and Mairi Go to War: Two Extraordinary Women on the Western Front (London: Preface Publishing, 2009): 39-64.

31 Atkinson, Elsie and Mairi Go to War: 1; T'Serclaes, Flanders and Other Fields: $36-8$.

32 T'Serclaes, Flanders and Other Fields: 37.

33 Dorothie Fielding, Lady under Fire: The Wartime Letters of Lady Dorothie Fielding M.M., 1914-1917, ed. Andrew Hallam and Nicola Hallam (Barnsley: 
Pen and Sword Books, 2010); Macnaughtan, A Woman's Diary of the War; Anon., A War Nurse's Diary: 54-5; T'Serclaes, Flanders and Other Fields: 37.

34 T'Serclaes, Flanders and Other Fields: 41.

35 T'Serclaes, Flanders and Other Fields: 52-3.

36 Anon., A War Nurse's Diary: 67.

37 Binyon, For Dauntless France: 46-7.

38 Angela Smith, The Second Battlefield: Women, Modernism and the First World War (Manchester: Manchester University Press, 2000): 54.

39 Flora Sandes, An English Woman-Sergeant in the Serbian Army (London: Hodder and Stoughton, 1916): 8-9. See also: Flora Sandes, The Autobiography of a Woman Soldier: A Brief Record of Adventure with the Serbian Army, 1916-1919 (New York: Frederick A. Stokes, n.d.).

40 On the novels of Bessie Marchant, see: Michelle Smith, 'Adventurous Girls of the British Empire: The Pre-War Novels of Bessie Marchant', The Lion and the Unicorn, 33.1 (2009): 1-25.

41 Sandes, An English Woman-Sergeant: 19-21.

42 Smith, The Second Battlefield: 55-6.

43 Mabel St Clair Stobart, The Flaming Sword in Serbia and Elsewhere (London: Hodder and Stoughton, 1916): passim.

44 Stobart, Flaming Sword: 1-4.

45 Stobart, Flaming Sword: 1-4. On Mabel St Clair Stobart, see: Angela Smith, 'The Woman who Dared: Major Mabel St Clair Stobart', in Alison S. Fell and Ingrid Sharp (eds), The Women's Movement in Wartime: International Perspectives 1914-1918 (Basingstoke: Palgrave, 2007): 158-74.

46 On the formation of the WSWCC, see: Smith, The Second Battlefield: 50.

47 Stobart's unit travelled to Belgium under the auspices of the St John's Ambulance Association: Stobart, Flaming Sword: 5.

48 Stobart, Flaming Sword: 123-288. On the journeys made by the WSWCC and other Serbian units, see: Hallett, Veiled Warriors: Chapter 3.

49 Mark Bostridge, Florence Nightingale: The Woman and Her Legend (London: Viking, 2008): 251-4.

50 Angela Smith has commented on how significant this image was in conveying 'an inversion of expected gender roles': Smith, The Second Battlefield: 64-5.

51 Stobart, Flaming Sword. The account of the unit's journey across the Albanian Alps is between pp. 153 and 292.

52 Stobart, Flaming Sword: 313-14.

53 Catherine Marshall, Militarism versus Feminism (London: Virago, 1987 [1915]): passim.

54 E. Sylvia Pankhurst, The Home Front (London: Hutchinson, 1987 [1932]): passim.

55 Olive M. Aldridge, The Retreat from Serbia through Montenegro and Albania (London: Minerva, 1916): passim.

56 Ellen Chivers Davies, A Farmer in Serbia (London: Methuen, n.d.): 121. 
57 Anon., Column, BJN (8 January 1916): 29.

58 Macnaughtan, A Woman's Diary of the War: 41.

59 Sarah Macnaughtan, My War Experiences in Two Continents, ed. Mrs Lionel Salmon [Betty Keays-Young] (London: John Murray, 1919).

60 Macnaughtan, A Woman's Diary of the War: 52.

61 Macnaughtan, A Woman's Diary of the War: 163.

62 Macnaughtan, My War Experiences: 256.

63 Macnaughtan, My War Experiences: 256-7 (italics as in the original).

64 Macnaughtan, My War Experiences: conclusion.

65 Smith, The Second Battlefield: 54. 